\title{
Novel approach for testing the food limitation hypothesis in estuarine and coastal fish nurseries
}

\author{
A. Tableau*, H. Le Bris, E. Saulnier, O. Le Pape, A. Brind'Amour \\ *Corresponding author: adrien.tableau@gmail.com
}

\section{Supplement S1: Statistical distribution of the uncertain parameters}

The variance $(\mathrm{V})$ and the mean $(\mathrm{E})$ of literature data are used to define a beta distribution for ratio parameters (comprised between 0 and 1 ), and a gamma distribution for the strictly positive parameters. The relationships between the variance $(\mathrm{V})$ and the mean $(\mathrm{E})$ of data to the shape parameters of the beta distribution $(\alpha$ and $\beta$ ), and to the shape $(\alpha)$ and rate $(\beta)$ parameters of the gamma distribution are:

beta distribution coefficients:

$$
\begin{aligned}
& \alpha=\frac{E\left(E-E^{2}-V\right)}{V} \\
& \beta=\frac{(1-E)\left(E-E^{2}-V\right)}{V}
\end{aligned}
$$

gamma distribution coefficients:

$$
\begin{aligned}
& \alpha=\frac{E^{2}}{V} \\
& \beta=\frac{E}{V}
\end{aligned}
$$

A parameter defined as a variable $X$ whose logarithm is normally distributed (with a known mean: $E$ and a known variance: $V$ ) follows a log-normal distribution, which is directly defined by $E$ and $V$. The mean $\left(E^{\prime}\right)$ of $X$ can be expressed in function of the mean $(\mathrm{E})$ and variance $(\mathrm{V})$ of $\log (\mathrm{X})$ :

mean of lognormal distribution: $\quad E^{\prime}=e^{\left(E+\frac{V}{2}\right)}$

An exception is applied to the parameter $\mathrm{K}$, which is in the denominator of the consumption equation. Indeed, if $\mathrm{K}$ follows a beta distribution, the distribution of $1 / \mathrm{K}$ is unknown and has an unstable mean. $\mathrm{K}$ is thus defined with a gamma distribution. Therefore, $1 / \mathrm{K}$ is defined as an inverse gamma distribution, which is defined by the shape $(\alpha)$ and rate $(\beta)$ parameters of the $K$ distribution. The mean $\left(E^{\prime}\right)$ of $1 / K$ can be expressed in function of the mean $(\mathrm{E})$ and variance $(\mathrm{V})$ of $\mathrm{K}$ :

mean of inverse gamma distribution: $\quad E^{\prime}=\frac{E}{\left(E^{2}-V\right)} \quad$ with the constraint: $V<E^{2}$ 


\section{Supplement S2: data collection for the Bay of Vilaine}

\section{Survey data}

\section{Macrobenthic invertebrate biomass and fish abundance}

Given the mismatch in the locations of the sampling stations between the two surveys (fish and invertebrates) and the uneven spatial distribution of the sampling effort, we stratified the bay of Vilaine in three zones (Figure 1, which is a simplification of the 5 habitats defined by Kopp et al. 2013). Splitting is necessary because the sampling efforts of fish and benthic invertebrates decrease from zone 1 to zone 2 , and zone 3 (respectively 3.4 stations. $\mathrm{km}^{-2}, 2.0$ stations. $\mathrm{km}^{-2}$, and 1.5 stations. $\mathrm{km}^{-2}$ for fish sampling; and respectively 0.42 stations. $\mathrm{km}^{-2}, 0.17$ stations. $\mathrm{km}^{-2}$, and 0.17 stations. $\mathrm{km}^{-2}$ for benthic invertebrate sampling). Therefore, for each cohort/species, the average abundance/biomass is computed in each zone and raised to the surface area to provide a total abundance/biomass. Bootstrap method is used to estimate the uncertainty on total abundance/biomass of each cohort/species.

\section{Fish weight-length relationships}

For each haul of the survey, fish are weighed by species all together, and they are all individually measured (a subsample is measured if the number exceeds 30 individuals). An observation is described as follows:

$$
\mathrm{W}_{\mathrm{h}}=\sum_{\mathrm{n} \in 1: \mathrm{N}} \mathrm{a} \cdot \mathrm{L}_{\mathrm{n}}^{\mathrm{b}}
$$

$\mathrm{W}_{\mathrm{h}}$ is the weight in $\mathrm{g}$. of all individuals of a single species in the haul $\mathrm{h} ; \mathrm{L}_{\mathrm{n}}$ in $\mathrm{mm}$ is the length of the $\mathrm{n}^{\text {th }}$ fish individual; $a$ and $b$, the parameters of the relationship. These parameters are then estimated using all observations with an optimization algorithm in the software R (R Core Team 2012).

Table S1: weight-length parameters (weight in $\mathrm{g}$ and length in $\mathrm{mm}$ )

\begin{tabular}{lll} 
Species & a & b \\
\hline Dicologlossa cuneata & $3.028 \mathrm{e}-5$ & 2.723 \\
Pleuronectes platessa & $1.369 \mathrm{e}-5$ & 2.953 \\
Solea solea & $9.237 \mathrm{e}-6$ & 2.994 \\
Mullus surmuletus & $7.636 \mathrm{e}-6$ & 3.121 \\
Merlangius merlangus & $9.749 \mathrm{e}-6$ & 2.972 \\
Merluccius merluccius & $5.454 \mathrm{e}-6$ & 3.055 \\
Trisopterus luscus & $9.705 \mathrm{e}-6$ & 3.054 \\
\hline
\end{tabular}

\section{Literature data}

\section{Macrobenthic invertebrates}

Table S2: Summary of macrobenthic invertebrate parameters.

\begin{tabular}{llll} 
Parameter & Value or range of values & Uncertainty details & Source \\
\hline $\begin{array}{l}\text { Conversion ratio (CR) } \\
\begin{array}{l}\text { Production-to-biomass ratio } \\
\text { (P:B) }\end{array}\end{array}$ & 0.672 & sd 0.0 .0111 & survey \\
Regeneration (R) & $0-0.5$ & sd range: $0.0356-1.988$ & (Brey 2012) \\
Energy conversion (E) & $\begin{array}{l}0.851-6.694 \mathrm{~kJ}^{-1} \\
\text { Easily accessible : } 1\end{array}$ & Conservative approach & various sources \\
Accessibility (A) & Hardly accessible : 0.117 & $\mathrm{sd}=0.0485$ & (Brey et al. 2010) \\
\hline
\end{tabular}

Additional details on these parameters are provided in Tableau et al 2015 for the 94 taxa. 


\section{Fish juveniles}

Table S3: Fish data compiled from the literature. ${ }^{*}$ As Merluccius merluccius shifts to an exclusive fish diet after $150 \mathrm{~mm}$, this proportion becomes 0 for larger fish.

\begin{tabular}{|c|c|c|c|c|c|c|c|c|}
\hline fish & $\begin{array}{l}\text { Dicologlos } \\
\text { sa } \\
\text { cuneata }\end{array}$ & $\begin{array}{l}\text { Pleuronectes } \\
\text { platessa }\end{array}$ & $\begin{array}{l}\text { Solea } \\
\text { solea }\end{array}$ & $\begin{array}{l}\text { Solea } \\
\text { solea }\end{array}$ & $\begin{array}{l}\text { Mullus } \\
\text { surmuletus }\end{array}$ & $\begin{array}{l}\text { Merlangius } \\
\text { merlangus }\end{array}$ & $\begin{array}{l}\text { Merluccius } \\
\text { merluccius }\end{array}$ & $\begin{array}{l}\text { Trisopterus } \\
\text { luscus }\end{array}$ \\
\hline age group & G1 & G0 & G0 & G1 & G0 & G0 & G0 & G0 \\
\hline shape & flatfish & flatfish & flatfish & flatfish & roundfish & roundfish & roundfish & roundfish \\
\hline diet & $\begin{array}{l}\text { exclusive } \\
\text { benthivore }\end{array}$ & $\begin{array}{l}\text { exclusive } \\
\text { benthivore }\end{array}$ & $\begin{array}{l}\text { exclusive } \\
\text { benthivore }\end{array}$ & $\begin{array}{l}\text { exclusive } \\
\text { benthivore }\end{array}$ & $\begin{array}{l}\text { exclusive } \\
\text { benthivore }\end{array}$ & $\begin{array}{l}\text { partial } \\
\text { benthivore }\end{array}$ & $\begin{array}{l}\text { partial } \\
\text { benthivore }\end{array}$ & $\begin{array}{l}\text { partial } \\
\text { benthivore }\end{array}$ \\
\hline $\mathrm{Ld}_{0}(\mathrm{~mm})$ & 110 & 70 & 70 & 110 & 70 & 70 & 70 & 70 \\
\hline do & April 11 & August 7 & July 31 & May 21 & August 11 & July 12 & April 9 & July 9 \\
\hline G $\left(\mathrm{mm} . \mathrm{day}^{-1}\right)$ & 0.38 & 0.51 & 0.60 & 0.60 & 0.77 & 0.79 & 0.67 & 0.83 \\
\hline$Z\left(\right.$ day $\left.^{-1}\right)$ & 0.0179 & 0.0171 & 0.0179 & 0.0179 & 0.0103 & 0.00760 & 0.00765 & 0.00770 \\
\hline q & 0.257 & 0.380 & 0.257 & 0.257 & 0.500 & 0.500 & 0.500 & 0.500 \\
\hline DC & 1 & 1 & 1 & 1 & 1 & 0.5 & $0.27^{*}$ & 0.75 \\
\hline$E\left(k J . g^{-1}\right)$ & 5.78 & 5.66 & 5.78 & 5.78 & 6.88 & 6.24 & 6.24 & 6.24 \\
\hline E sd & 0.618 & 0.802 & 0.618 & 0.618 & 1.69 & 0.805 & 0.805 & 0805 \\
\hline K & 0.197 & 0.316 & 0.197 & 0.197 & 0.312 & 0.385 & 0.385 & 0.385 \\
\hline$K$ sd & 0.0675 & 0.0792 & 0.0675 & 0.0675 & 0.0969 & 0.0720 & 0.0720 & 0.0720 \\
\hline
\end{tabular}

\section{Growth period and growth rate}

The main growth period of fish juveniles in temperate ecosystems is ranging from spring to fall and is very consistent over many fish species (Forest 1975, Gordon 1977, Desaunay et al. 1981, Van Der Veer et al. 1990, Hamerlynck \& Hostens 1993, Shi et al. 1997, Amara 2004, Otxotorena et al. 2010). This is explained by lower food intake during winter (Zanuy \& Carrillo 1985). By conservative approach, we focus only on the food intake during the main growth period in summer. As a growth decrease is generally observed during fall, we set the end of the growth period in our model on October 1 (early fall). For G0 fish, the beginning of the growth period is deduced from the growth rate and the fish size from which they eat on macrobenthic invertebrates (set at $70 \mathrm{~mm}$, see Tableau et al. 2016). For G1 Solea solea, the length at the beginning of the growth period is associated to the length of $\mathrm{G} 0$ at the end of the growth period $(11 \mathrm{~cm})$, this is supported by the observations in Desaunay et al. (1981). As no G0 Dicologlossa cuneata are observed, we use the same length for $\mathrm{G} 1$ Dicologlossa cuneata. This assumption is supported by the observations in Forest (Forest 1975).

The growth rates can vary over time and among the nursery habitats (Ciotti et al. 2014). The general strategy was to use data corresponding to the closest habitats of the bay of Vilaine when no local data were available. When length time series were available, the match with the fish length observed in the survey was checked (Forest 1975, Gordon 1977, Desaunay et al. 1981, Van Der Veer et al. 1990, Hamerlynck \& Hostens 1993, Shi et al. 1997, Amara 2004, Otxotorena et al. 2010). The conservative approach for the growth period limits the potential overestimation of the exploitation efficiency. 
Table S4: growth data collection ( $\mathrm{G} 0$ for young of the year and $\mathrm{G} 1$ for one year old)

\begin{tabular}{|c|c|c|c|c|}
\hline Species & Age group & $\begin{array}{l}\text { Growth rate } \\
\left(\mathrm{mm} \cdot \text { day }^{-1}\right)\end{array}$ & Source & Comment \\
\hline Dicologlossa cuneata & G1 & 0.38 & Forest 1975 & graphic analysis on local data \\
\hline Pleuronectes platessa & G0 & 0.51 & Amara 2004 & local data \\
\hline Solea solea & G0 & 0.60 & Marchand 1991 & local data \\
\hline Solea solea & G1 & 0.60 & $\begin{array}{l}\text { Desaunay et al. 1981, } \\
\text { Marchand } 1991\end{array}$ & local data \& graphic analysis on local data \\
\hline Mullus surmuletus & G0 & 0.77 & N'Da and Deniel 2005 & data analysis on local data \\
\hline Merlangius merlangus & G0 & 0.79 & $\begin{array}{l}\text { Hamerlynck and } \\
\text { Hostens } 1993\end{array}$ & $\begin{array}{l}\text { graphic analysis on external data - good } \\
\text { match between lengths at the same period }\end{array}$ \\
\hline Merluccius merluccius & G0 & 0.67 & $\begin{array}{l}\text { Kacher and Amara } \\
2005 \text {, Otxotorena et } \\
\text { al. } 2010\end{array}$ & average on two local data \\
\hline Trisopterus luscus & G0 & 0.83 & $\begin{array}{l}\text { Hamerlynck and } \\
\text { Hostens } 1993\end{array}$ & $\begin{array}{l}\text { graphic analysis on external data - good } \\
\text { match between lengths at the same period }\end{array}$ \\
\hline
\end{tabular}

\section{Mortality rate}

The mortality rates vary among nursery habitats and over time (lles \& Beverton 1991). In the exploitation efficiency analysis, emigration and natural mortality can be confounded as it results in a decrease of food consumption anyway. Mortality rates are available only for two flatfish species and are used for the others. A single data is available for three roundfish species, the average of the two Gadiformes species (Merlangius merlangus and Trisopterus luscus) is used for Merluccius merluccius:

Pleuronectes platessa (51 data): mean $=0.0171 \mathrm{nb}^{- \text {day }^{-1}} \& \mathrm{sd}=0.0088$ (Iles \& Beverton 1991, Modin \& Pihl 1994, Nash \& Geffen 2012)

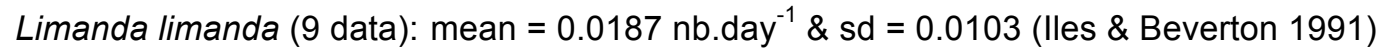

Mullus surmuletus ( 1 data): mean $=0.0103$ (N'Da \& Deniel 2005)

Merlangius merlangus (1 data): mean $=0.0076($ Hamerlynck \& Hostens 1993)

Trisopterus luscus (1 data): mean $=0.0077$ (Hamerlynck \& Hostens 1993)

As the survey is done around the middle of the growth period (August 22), errors in mortality rates have small consequences: an overestimated mortality would result in a higher consumption estimate on the time period before the survey, but a lower one on the period after the survey. As we want to estimate the exploitation on the full time period, the lack of accuracy of this parameter is acceptable.

\section{Catch efficiency}

Catch efficiency data have been estimated in several studies on various flatfish species including Pleuronectes platessa and Solea solea. The catch efficiencies are most likely overestimated in these studies given the experimental protocols (e.g Kuipers 1975). Consequently, fish abundances are probably underestimated, which fits with the conservative approach. First, available data have been compiled per study and then averaged over the different studies. Solea solea value has been attributed to Dicologlossa cuneata given their close phylogeny (Soleidae family). Data on roundfish species are scarcer but conservative data are suggested for Merlangus merlangius and Trisopterus luscus. This data has been associated to the roundfish Mullus surmulutus and Merluccius merluccius. 
Table S5: catch efficiency data

\begin{tabular}{llll} 
Species & q & Trawl & Source \\
\hline Pleuronectes platessa & $50.6 \%$ & 2 m beam trawl & (Rogers \& Lockwood 1989) \\
Pleuronectes platessa & $28.4 \%$ & 2 m beam trawl & (Kuipers 1975) \\
Pleuronectes platessa & $39.5 \%$ & 2 m beam trawl & (Kuipers 1975) \\
Pleuronectes platessa & $33.5 \%$ & 2 m beam trawl & (Edwards \& Steele 1968) \\
Solea solea & $25.7 \%$ & 2 m beam trawl & (Rogers \& Lockwood 1989) \\
Merlangius merlangus & $50.0 \%$ & 3 m beam trawl & (Hamerlynck \& Hostens 1993) \\
Trisopterus luscus & $50.0 \%$ & 3 m beam trawl & (Hamerlynck \& Hostens 1993) \\
\hline
\end{tabular}

\section{Diet}

The first age groups of the three flatfish species are exclusive benthivorous species (Amara et al. 2001, Le Loc'h 2004). Mullus surmulletus is also an exclusive benthivore (N'da 1992). Based on the gravimetric proportion of benthic invertebrate prey observed in gut contents of G0 Merlangius merlangus and Trisopterus luscus (Hamerlynck \& Hostens 1993), the estimated proportions are $50 \%$ and $75 \%$ respectively. Based on Mahe et al. (2007), the proportions in the Merluccius merluccius diet of benthic invertebrates are averaged over three regions (27\%). As G0 Merluccius merluccius diet shifts from a mix of fish and benthic invertebrates to only fish around $15 \mathrm{~mm}$, the proportion is set to 0 after $150 \mathrm{~mm}$ (Le Loc'h 2004, Mahe et al. 2007).

\section{Energy density}

An investigation has been done on all articles of the journals "Aquaculture", "Aquaculture nutrition" and "Aquaculture research". A complementary research in all journals has been done with the keywords "Body composition" "energy density". The body composition is often described as a proportion of proteins, lipids, glycogen, and water. Energy conversion coefficients have been compiled from different studies (Brett \& Groves 1979, Brafield 1985, Cho \& Kaushik 1990, Jobling 1993).

Proteins: $23.7 \mathrm{~kJ}^{-g^{-1}}$

Lipids: $36.3 \mathrm{~kJ} . \mathrm{g}^{-1}$

Glycogen: $17.2 \mathrm{~kJ} . \mathrm{g}^{-1}$

Water: 0kJ.g ${ }^{-1}$

As adult body composition varies with the reproduction season, only juvenile data are used. Pelagic fish data are rejected as this kind of fish has a higher fat concentration. Data corresponding to fish fed with high fat food are rejected. All data referring only to the flesh or the liver were also rejected. Among the 186 data collected, 62 referring to the fish taxa Gadidae, Perciformes, Pleuronectidae, and Soleidae were used. The average and the standard deviation of the corresponding taxa are attributed to each species. 25 references are used (Pandian 1970, Holdway \& Beamish 1984, Smith et al. 1986, Hidalgo et al. 1987, Costopoulos \& Fonds 1989, Marais 1990, Imsland et al. 2000, Lee et al. 2003, Person-Le Ruyet et al. 2004, Dias et al. 2004, Rosenlund et al. 2004, Tibbetts et al. 2005, Rema et al. 2008, Borges et al. 2009, Silva et al. 2010, Ding et al. 2010, Gatta et al. 2011, Li et al. 2012, Marinho et al. 2014, Guerreiro et al. 2015, Bonvini et al. 2015, López et al. 2016, Zhang et al. 2016, Li et al. 2017, Salas-Leiton et al. 2017).

\section{Gross conversion efficiency (growth-to-food intake ratio)}

An investigation has been done on all articles of the journals "Aquaculture", "Aquaculture nutrition" and "Aquaculture research". A complementary research has been done in all journals with the keywords "growth efficiency energy", "gross growth efficiency energy", "gross conversion efficiency energy", "food conversion efficiency energy", "feed conversion efficiency energy". Data collected in winter are rejected as lower temperature gives lower conversion efficiency (e.g.Zanuy \& Carrillo 1985). When conversion efficiency data are estimated on a temperature gradient, we take only values around the optimal temperature. When data refer to weight conversion efficiency, we convert the production and the consumption in energy when possible. Gross conversion efficiencies are higher for young fish as no energy is allocated to reproduction. Thus, we use only gross conversion efficiencies referring to fish juveniles (Mateo 2007). We used 189 data referring to the fish taxa Gadidae, Perciformes, Pleuronectidae, and Soleidae. As these data mostly come from aquaculture studies, they are expected to be a bit higher than the gross conversion efficiency occurring in natural environment. The exploitation efficiencies are consequently likely underestimated. The average 
and the standard deviation of the corresponding taxa are attributed to each species. 31 references are used (Pandian 1970, Edwards et al. 1972, Marais \& Kissil 1979, Hidalgo et al. 1987, Fonds et al. 1992,

Hamerlynck \& Hostens 1993, Lankford \& Targett 1994, Buckel et al. 1995, Björnsson \& Tryggvadóttir 1996, Deacon \& Hecht 1999, Imsland et al. 2000, Kim \& Lall 2001, Kim et al. 2001, Peck et al. 2003, Person-Le Ruyet et al. 2004, Dias et al. 2004, Rosenlund et al. 2004, Tibbetts et al. 2005, Mateo 2007, Rema et al. 2008, Borges et al. 2009, Silva et al. 2010, Ding et al. 2010, Gatta et al. 2011, Guerreiro et al. 2012, Li et al. 2012, Bonvini et al. 2015, López et al. 2016, Zhang et al. 2016, Li et al. 2017, Salas-Leiton et al. 2017).

\section{References}

Amara R (2004) 0-group flatfish growth conditions on a nursery ground (Bay of Canche, Eastern English Channel). Hydrobiologia 518:23-32

Amara R, Laffargue P, Dewarumez JM, Maryniak C, Lagardére F, Luzac C (2001) Feeding ecology and growth of O-group flatfish (sole, dab and plaice) on a nursery ground (Southern Bight of the North Sea). J Fish Biol 58:788-803

Björnsson B, Tryggvadóttir SV (1996) Effects of size on optimal temperature for growth and growth efficiency of immature Atlantic halibut (Hippoglossus hippoglossus L.). Aquaculture 142:33-42

Bonvini E, Parma L, Mandrioli L, Sirri R, Brachelente C, Mongile F, Gatta PP, Bonaldo A (2015) Feeding common sole (Solea solea) juveniles with increasing dietary lipid levels affects growth, feed utilization and gut health. Aquaculture 449:87-93

Borges P, Oliveira B, Casal S, Dias J, Conceição L, Valente LMP (2009) Dietary lipid level affects growth performance and nutrient utilisation of Senegalese sole (Solea senegalensis) juveniles. Br J Nutr 102:1007-1014

Brafield AE (1985) Laboratory Studies of Energy Budgets. In: Tytler P, Calow P (eds) Fish Energetics. Springer Netherlands, p 257-281

Brett JR, Groves TDD (1979) Physiological energetics. In: Fish Physiology. Academic Press, New York, p 280-352

Brey T (2012) A multi-parameter artificial neural network model to estimate macrobenthic invertebrate productivity and production. Limnol Oceanogr-Methods 10:581-589

Brey T, Mueller-Wiegmann C, Zittier ZMC, Hagen W (2010) Body composition in aquatic organisms - A global data bank of relationships between mass, elemental composition and energy content. J Sea Res 64:334-340

Buckel JA, Steinberg ND, Conover DO (1995) Effects of temperature, salinity, and fish size on growth and consumption of juvenile bluefish. J Fish Biol 47:696-706

Cho CY, Kaushik SJ (1990) Nutritional energetics in fish: energy and protein utilization in rainbow trout (Salmo gairdneri). In: Aspects of food production, consumption and energy values. Karger Publishers, p 132-172

Ciotti BJ, Targett TE, Nash RDM, Geffen AJ (2014) Growth dynamics of European plaice Pleuronectes platessa L. in nursery areas: A review. J Sea Res 90:64-82

Costopoulos CG, Fonds M (1989) Proximate body composition and energy content of plaice (Pleuronectes platessa) in relation to the condition factor. Neth J Sea Res 24:45-55

Deacon N, Hecht T (1999) The effect of reduced salinity on growth, food conversion and protein efficiency ratio in juvenile spotted grunter, Pomadasys commersonnii (Lacépède) (Teleostei: Haemulidae). Aquac Res 30:13-20

Desaunay Y, Perddou JB, Beillois P (1981) Etude des nurseries de poissons du littoral de la LoireAtlantique. Sci Pêche 319:1-23 
Dias J, Rueda-Jasso R, Panserat S, Conceição LEC da, Gomes EF, Dinis MT (2004) Effect of dietary carbohydrate-to-lipid ratios on growth, lipid deposition and metabolic hepatic enzymes in juvenile Senegalese sole (Solea senegalensis, Kaup). Aquac Res 35:1122-1130

Ding L, Zhang L, Wang J, Ma J, Meng X, Duan P, Sun L, Sun Y (2010) Effect of dietary lipid level on the growth performance, feed utilization, body composition and blood chemistry of juvenile starry flounder (Platichthys stellatus). Aquac Res 41:1470-1478

Edwards RRC, Finlayson DM, Steele JH (1972) An experimental study of the oxygen consumption, growth, and metabolism of the cod (Gadus Morhua L.). J Exp Mar Biol Ecol 8:299-309

Edwards R, Steele JH (1968) The ecology of 0-group plaice and common dabs at Loch Ewe I. Population and food. J Exp Mar Biol Ecol 2:215-238

Fonds M, Cronie R, Vethaak AD, Van Der Puyl P (1992) Metabolism, food consumption and growth of plaice (Pleuronectes platessa) and flounder (Platichthys flesus) in relation to fish size and temperature. Neth J Sea Res 29:127-143

Forest A (1975) Le ceteau Dicologoglossa cunetata (Moreau), sa biologie et sa peche dans le sud du golfe de Gasgogne. Rev Trav Inst Pêch Marit 39:5-62

Gatta PP, Parma L, Guarniero I, Mandrioli L, Sirri R, Fontanillas R, Bonaldo A (2011) Growth, feed utilization and liver histology of juvenile common sole (Solea solea L.) fed isoenergetic diets with increasing protein levels. Aquac Res 42:313-321

Gordon JDM (1977) The fish populations in inshore waters of the West Coast of Scotland. The distribution, abundance and growth of the whiting (Merlangius merlangus L.). J Fish Biol 10:587-596

Guerreiro I, Enes P, Merrifield D, Davies S, Oliva-Teles A (2015) Effects of short-chain fructooligosaccharides on growth performance and hepatic intermediary metabolism in turbot (Scophthalmus maximus) reared at winter and summer temperatures. Aquac Nutr 21:433-443

Guerreiro I, Peres H, Castro-Cunha M, Oliva-Teles A (2012) Effect of temperature and dietary protein/lipid ratio on growth performance and nutrient utilization of juvenile Senegalese sole (Solea senegalensis). Aquac Nutr 18:98-106

Hamerlynck O, Hostens K (1993) Growth, feeding, production, and consumption in 0-group bib (Trisopterus luscus L.) and whiting (Merlangius merlangus L.) in a shallow coastal area of the south-west Netherlands. ICES J Mar Sci J Cons 50:81-91

Hidalgo F, Alliot E, Thebault $H$ (1987) Influence of water temperature on food intake, food efficiency and gross composition of juvenile sea bass, Dicentrarchus labrax. Aquaculture 64:199-207

Holdway DA, Beamish FWH (1984) Specific growth rate and proximate body composition of Atlantic cod (Gadus morhua L.). J Exp Mar Biol Ecol 81:147-170

Iles TC, Beverton RJH (1991) Mortality rates of 0-group plaice (Pleuronectes platessa L.), dab (Limanda limanda L.) and turbot (Scophthalmus maximus L.) in European waters: I. Statistical analysis of the data and estimation of parameters. Neth J Sea Res 27:217-235

Imsland AK, Jonassen TM, Stefansson SO, Kadowaki S, Berntssen MHG (2000) Intraspecific Differences in Physiological Efficiency of Juvenile Atlantic Halibut Hippoglossus hippoglossus L. J World Aquac Soc 31:285-296

Jobling M (1993) Bioenergetics: feed intake and energy partitioning. In: Rankin JC, Jensen FB (eds) Fish Ecophysiology. Springer Netherlands, p 1-44

Kacher M, Amara R (2005) Distribution and growth of 0-group European hake in the Bay of Biscay and Celtic Sea: a spatial and inter-annual analyses. Fish Res 71:373-378 
Kim J-D, Lall SP (2001) Effects of dietary protein level on growth and utilization of protein and energy by juvenile haddock (Melanogrammus aeglefinus). Aquaculture 195:311-319

Kim JD, Lall SP, Milley JE (2001) Dietary protein requirements of juvenile haddock (Melanogrammus aeglefinus L.). Aquac Res 32:1-7

Kopp D, Le Bris H, Grimaud L, Nerot C, Brind'Amour A (2013) Spatial analysis of the trophic interactions between two juvenile fish species and their preys along a coastal-estuarine gradient. J Sea Res 81:40-48

Kuipers B (1975) On the efficiency of a two-metre beam trawl for juvenile plaice (Pleuronectes Platessa). Neth J Sea Res 9:69-85

Lankford TE, Targett TE (1994) Suitability of estuarine nursery zones for juvenile weakfish (Cynoscion regalis): effects of temperature and salinity on feeding, growth and survival. Mar Biol 119:611-620

Le Loc'h F (2004) Structure, functioning and evolution of exploited soft sediment benthic communities of the North Bay of Biscay continental shelf. Université de Bretagne occidentale - Brest

Lee S-M, Lee JH, Kim K-D (2003) Effect of dietary essential fatty acids on growth, body composition and blood chemistry of juvenile starry flounder (Platichthys stellatus). Aquaculture 225:269-281

Li Y, Ai Q, Mai K, Xu W, Cheng Z (2012) Effects of the partial substitution of dietary fish meal by two types of soybean meals on the growth performance of juvenile Japanese seabass, Lateolabrax japonicus (Cuvier 1828). Aquac Res 43:458-466

Li W, Wen X, Huang Y, Zhao J, Li S, Zhu D (2017) Effects of varying protein and lipid levels and protein-toenergy ratios on growth, feed utilization and body composition in juvenile Nibea diacanthus. Aquac Nutr

López LM, Olmos Soto J, Trejo Escamilla I, Flores Ibarra M, Ochoa L, Drawbridge M, Peres H (2016) Evaluation of carbohydrate-to-lipid ratio in diets supplemented with Bacillus subtilis probiotic strain on growth performance, body composition and digestibility in juvenile white seabass (Atractoscion nobilis, Ayres 1860). Aquac Res 47:1864-1873

Mahe K, Amara R, Bryckaert T, Kacher M, Brylinski JM (2007) Ontogenetic and spatial variation in the diet of hake (Merluccius merluccius) in the Bay of Biscay and the Celtic Sea. ICES J Mar Sci J Cons 64:1210-1219

Marais JFK (1990) Body composition of ten marine migrants and one freshwater fish species caught in estuaries of the Eastern Cape, South Africa. South Afr J Mar Sci 9:135-140

Marais JFK, Kissil GW (1979) The influence of energy level on the feed intake, growth, food conversion and body composition of Sparus aurata. Aquaculture 17:203-219

Marchand J (1991) The influence of environmental conditions on settlement, distribution and growth of 0group sole (Solea solea (L.)) in a macrotidal estuary (Vilaine, France). Neth J Sea Res 27:307-316

Marinho G, Peres H, Carvalho AP (2014) Effect of feeding time on dietary protein utilization and growth of juvenile Senegalese sole (Solea senegalensis). Aquac Res 45:828-833

Mateo I (2007) A bioenergetics based comparison of growth conversion efficiency of Atlantic cod on Georges Bank and in the Gulf of Maine. J Northwest Atl Fish Sci

Modin J, Pihl L (1994) Differences in growth and mortality of juvenile plaice, Pleuronectes platessa L., following normal and extremely high settlement. Neth J Sea Res 32:331-341

Nash RDM, Geffen AJ (2012) Mortality through the early life-history of fish: What can we learn from European plaice (Pleuronectes platessa L.)? J Mar Syst 93:58-68 
N'da K (1992) Régime alimentaire du rouget de roche Mullus surmuletus (Mullidae) dans le nord du Golfe de Gascogne. Cybium 16:159-167

N'Da K, Deniel C (2005) Croissance des juvéniles du rouget de roche (Mullus surmuletus) dans le nord du golfe de Gascogne. Cybium 29:175-178

Otxotorena U, Díez G, Abechuco EL de, Santurtún M, Lucio P (2010) Estimation of age and growth of juvenile hakes (Merluccius merluccius Linneaus, 1758) of the Bay of Biscay and Great Sole by means of the analysis of macro and microstructure of the otoliths. Fish Res 106:337-343

Pandian TJ (1970) Intake and conversion of food in the fish Limanda limanda exposed to different temperatures. Mar Biol 5:1-17

Peck MA, Buckley L, Caldarone E, Bengtson D (2003) Effects of Food Consumption and Temperature on Growth Rate and Biochemical-Based Indicators of Growth in Early Juvenile Atlantic Cod Gadus morhua and Haddock Melanogrammus aeglefinus. Fish Anim Vet Sci Fac Publ

Person-Le Ruyet J, Mahé K, Le Bayon N, Le Delliou H (2004) Effects of temperature on growth and metabolism in a Mediterranean population of European sea bass, Dicentrarchus labrax. Aquaculture 237:269-280

R Core Team (2012) R: A Language and Environment for Statistical Computing. R Foundation for Statistical Computing, Vienna, Austria

Rema P, Conceição L e. C., Evers F, Castro-Cunha M, Dinis M t., Dias J (2008) Optimal dietary protein levels in juvenile Senegalese sole (Solea senegalensis). Aquac Nutr 14:263-269

Rogers SI, Lockwood SJ (1989) Observations on the capture efficiency of a two-metre beam trawl for juvenile flatfish. Neth J Sea Res 23:347-352

Rosenlund G, Karlsen $\varnothing$, Tveit K, Mangor-Jensen A, Hemre G-I (2004) Effect of feed composition and feeding frequency on growth, feed utilization and nutrient retention in juvenile Atlantic cod, Gadus morhua L. Aquac Nutr 10:371-378

Salas-Leiton E, Conde-Sieira M, Pelusio N, Marques A, Maia M r. g., Soengas J I., Valente L m. p. (2017) Dietary protein/carbohydrate ratio in low-lipid diets for Senegalese sole (Solea senegalensis, Kaup 1858) juveniles. Influence on growth performance, nutrient utilization and flesh quality. Aquac Nutr:n/a-n/a

Shi YB, Gunderson DR, Sullivan PJ (1997) Growth and survival of O(+) English sole, Pleuronectes vetulus, in estuaries and adjacent nearshore waters off Washington. Fish Bull 95:161-173

Silva JMG, Espe M, Conceição LEC, Dias J, Costas B, Valente LMP (2010) Feed intake and growth performance of Senegalese sole (Solea senegalensis Kaup, 1858) fed diets with partial replacement of fish meal with plant proteins. Aquac Res 41:e20-e30

Smith RL, Paul AJ, Paul JM (1986) Effect of food intake and temperature on growth and conversion efficiency of juvenile walleye pollock (Theragra chalcogramma (Pallas)): a laboratory study. ICES J Mar Sci 42:241-253

Tableau A, Brind'Amour A, Woillez M, Le Bris H (2016) Influence of food availability on the spatial distribution of juvenile fish within soft sediment nursery habitats. J Sea Res 111:76-87

Tibbetts S m., Lall S p., Milley J e. (2005) Effects of dietary protein and lipid levels and DP DE-1 ratio on growth, feed utilization and hepatosomatic index of juvenile haddock, Melanogrammus aeglefinus $\mathrm{L}$. Aquac Nutr 11:67-75

Van Der Veer HW, Creutzberg F, Dapper R, Duineveld GCA, Fonds M, Kuipers BR, Van Noort GJ, Witte JIJ (1990) On the ecology of the dragonet Callionymus lyra L. in the southern North Sea. Neth J Sea Res 26:139-150 
Zanuy S, Carrillo M (1985) Annual cycles of growth, feeding rate, gross conversion efficiency and hematocrit levels of sea bass (Dicentrarchus labrax L.) adapted to two different osmotic media. Aquaculture 44:11-25

Zhang C -x., Huang F, Li J, Wang L, Song K, Mai K -s. (2016) Interactive effects of dietary magnesium and vitamin $\mathrm{E}$ on growth performance, body composition, blood parameters and antioxidant status in Japanese seabass (Lateolabrax japonicus) fed oxidized oil. Aquac Nutr 22:708-722 